\title{
The AU Debacle with the ICC: The Creation of the African Criminal Court
}

\author{
Aghem Hanson Ekori \\ College of Law, University of South Africa, Pretoria, South Africa
}

Email address:

48013587@mylife.unisa.ac.za, aghenh@yahoo.com

\section{To cite this article:}

Aghem Hanson Ekori. The AU Debacle with the ICC: The Creation of the African Criminal Court. International Journal of Law and Society. Vol. 4, No. 2, 2021, pp. 67-76. doi: 10.11648/j.ijls.20210402.12

Received: March 9, 2021; Accepted: March 25, 2021; Published: April 20, 2021

\begin{abstract}
Just like the churning of milk brings forth butter, the same could be said that the African Union (AU) debacle with the International Criminal Court (ICC) led to the creation of the African Criminal Court (ACC). Despite the initial support of the ICC by the AU and it state members during the creation process, the indictment of mostly senior serving African state officials by ICC when it came into force resulted in a devastating and tense relationship between the AU and the ICC. The creation of the ACC therefore was fast tacked by this unfriendly relationship between the AU and the ICC. This article argued that despite the tense relationship, harmonization of certain organs of the ACC and the ICC is necessary in the fight against impunity for the most serious crimes of international concern. In this regard, I examined the legality and legitimacy of the ACC and maintained that despite the immunity provision, it legality is consistent with international law, and accordingly, that the ACC is not the African panacea with respect to the fight against impunity for serious international crimes. Consequently, since the ACC and the ICC shared jurisdictions for the most serious crimes of international concern, harmonization of the ACC and the ICC through complementarity and cooperation will result in the formation of an undefeated tag team to fight against impunity for the most serious crimes affecting the international community.
\end{abstract}

Keywords: The ACC and the ICC, Impunity for international crimes, Legality and Legitimacy, Cooperation and Complementarity

\section{Introduction}

The ACC which was finally established in 2014 by the AU through a protocol was conceived many years ago. [1] Accordingly, this ACC which has not yet come into force was created 16 years after its conception in 1998, and on that same year the Rome Conference was held resulting in the creation of the ICC. Similarly, the ICC which was created by treaty after adoption and ratification by 120 states parties came into force on 1 July 2002. [2] It is therefore imperative to recall that African states greatly participated in the creation of the ICC and Senegal, an African state was the very first state in the world to ratify the Rome Statute creating the ICC. Unfortunately for the African states and the $\mathrm{AU}$, the euphoria which came with the creation of the first ever permanent international criminal court was short live. Since more than 90 percent of the cases referred to the jurisdiction of the Court were from the African continent and the suspects were senior African state officials protected by international immunities, [3] the AU has accused the ICC for targeting only African states officials since its creation even though this allegation has not yet been proven. The relationship between the ICC and AU became deteriorated when the ICC started indicting sitting AU heads of states especially President Uhuru Kenyatta and Vice President Ruto Williams of Kenya as well President Omar Al Bashir of Sudan. [4] Their indictments provoked the AU to hold a series of meetings which accelerated the process resulting in the establishment of the ACC in 2014; 12 years after the ICC came into force. Additionally, before the creation of the ICC, the AU and African state members had good and understandable relationship throughout all the processes leading to the creation of the ICC. However, the prosecution of mostly African state officials quickly reawakens the evils of colonization that the Western and European powers had caused during and after annexation of Africa. [5] This led the $\mathrm{AU}$ and some African leaders to quickly conclude that the ICC is targeting only African state officials. Perhaps, the 
prosecution of Al Bashir and Gadhafi through the UN Resolution supported by France and Britain in their capacity as permanent members of the UN was no doubt in the minds of the AU state members that indeed the ICC is a neocolonial tool set for Africans only. [6] The prosecution of these African state officials especially Presidents Al Bashir of Sudan and Kenyatta of Kenya sparked the AU debacle with the ICC. [7] Moreover, the legal framework behind the AU fiasco with the ICC is Articles 27 (2) and 98 (1) of the Rome Statute.[8] It is not surprising that the ACC recognized the immunity of senior serving African state officials before its jurisdiction which is directly contradictory to the jurisdiction of the ICC. [9]

As indicated earlier, the AU dissatisfaction with the ICC with regard to prosecution of senior serving state officials in the continent, [10] and particularly the work of the ICC's OTP over the Darfur crisis leading to the indictment of President Al Bashir fast-tracked the plans for the creation of a criminal chamber to the African Court of Justice and Human and People's Right (ACJHPR). This alone was the turning point in the Africa-ICC relationship and the peak of the AU debacle with the ICC despite the fact African state participated actively in the creation of the ICC. [11] Regrettably, the AU's accusation of the ICC is more emotional rather than legal. [12] It is truth that the ICC and the Office of the Prosecutor (OTP) should have used legal wisdom not to prosecute only African state officials given the fact that the legitimacy of the Court was not yet established since it was newly created. However, on a legal perspective, the ICC have jurisdiction over the crimes committed in African despite the fact that it has unfortunately concentrated in Africa. Therefore, the allegation that ICC is prosecuting or targeting only African state officials has not been proven. What has been proven is that the ICC have jurisdiction to entertain the alleged crimes committed in Africa and therefore prosecution of African state officials was legally justifiable. However, the issue of legitimacy of the Court was not justified given the fact that it focused on the prosecution of crimes committed only in one region of world, that is, the African continent, using it as the scapegoat during its first decade of operation.

After analysing the unfriendly relationship existing between the AU and the ICC which led to the creation of the ACC in Part I, Part II of this article will examine the legality and legitimacy of the ACC giving that its creation, and in particular the fact its recognizes the immunity of serving African senior officials before its jurisdiction has not been warmly receive by the international community. Part III will examine whether the ACC is the African panacea with regard to the fight against impunity for serious international crimes in the continent. Part IV will examine possible harmonization of the ACC and the ICC both at the horizontal level and at the vertical for impunity. Finally, Part V will deals with some concluding remarks.

\section{The Legality and Legitimacy of the ACC}

The creation of the ACC has raised many eyebrows among scholars and other institution considering the fact that the ICC is less than two decade of its existence, and therefore there was no need for another international criminal court. Other detractors thought that ACC may be redundant since the ICC has jurisdiction to entertain some of the most serious international crimes affecting mankind. Perhaps, the recognition of the personal immunities of African State officials before the jurisdiction of the $\mathrm{ACC}$ has been the main criticism labelled against the ACC. [13] In order to determine whether the allegations and criticism labelled against the creation of the ACC are justifiable, it is imperative to examine it legality and legitimacy. Therefore, in this section; I will examine the legality of the ACC under the United Nations (UN) Charter and AU Constitutive Act. I will also examine the legitimacy of the ACC and lastly, I will examine the legality and legitimacy of the immunity provision enshrined in Article 46A bis of the 2014 Malabo Protocol creating the ACC.

\subsection{The Legality of the ACC under the UN Charter and AU Constitutive Act}

To begin with, the concept of legality, according to Cassese, means the conformity or nonconformity of a body politic, or a national or international mechanism, with the legal rules that regulate its establishment. [14] Legality also means that the statutes of a particular jurisdiction are the basis for any act, agreement or contract in that jurisdiction and that no crime exists if an action is not a crime in that specific jurisdiction. [17] In other words, the prosecutor can only prosecute individuals that are criminally responsible before the jurisdiction of the ACC.

Now with regard to the issue of the legality of the ACC, it is imperative to assert that creation of the ACC is consistent with international law and the UN Charter. [18] In fact, there is no provision in the Rome Statute that prohibits the creation of an international regional court like the ACC. [19] According to Professor Charles Jalloh, modern enforcement system of international criminal law is based on three main pillars as follows: (i) there are prosecutions of international crimes within the national courts of the territorial states where the offense transpired; [20] (ii) there are prosecution within international court whether ad hoc or permanent such as the ICC and the ACC; [21] and (iii) contemporary international criminal law also considers prosecution within the domestic courts of the third state. [22]

The UN Charter recognizes regional arrangement aimed at maintaining international peace and security such as the ACC. Article 52 of the UN Charter provides as follows:

1. Nothing in the Charter precludes the existence of regional arrangements or agencies for dealing with such matters relating to the maintenance of peace and security as are appropriate for regional action provided 
that such arrangements or agencies and their activities are consistent with the Purposes and Principles of the United Nations.

2. The Members of the United Nations entering into such arrangements or constituting such agencies shall make every effort to achieve pacific settlement of local dispute through such regional arrangement or by such agencies before referring them to the Security Council.

3. The Security Council shall encourage the development of pacific settlement of local disputes through such regional arrangements or by such regional agencies either on the initiative of the states concerned or by reference from the Security Council.

The UN Charter encourages the creation of regional organisation like the AU to maintain peace and security in that region. The establishment of the ACC therefore, is consistent with international law despite the existence of the ICC. In other word, the ACC is neither redundant nor inconsistent with the Rome Statute creating the ICC and both courts can exist and exercise their respectively jurisdiction concurrently and harmoniously. Moreover, the UN Charter which also creates the Statute of the International Court of Justice (ICJ) further encourages the creation of other tribunals by UN state members besides the ICJ to settle their respective disputes as follows:

Nothing in the present Charter shall prevent Members of the United Nations from entrusting the solution of their differences to other tribunals by virtue of agreements already in existence or which may be concluded in the future. [23]

The ACC was created by the AU which falls under "agreements already in existence" as indicated above by Article 95 of the UN Charter. Moreover, the ACC is a product of the African Court of Justice and Human and Peoples' Rights (ACJHPR) created on 27 June 2014 at Malabo, Equatorial Guinea. [24] The ACJHPR is a merger of the African Court of Human and Peoples Rights and the Court of Justice of the African Union amended by the AU. [25] The central drive of the protocol was to create and institute a criminal chamber to the ACJHPR which is now called the ACC. [26] Additionally, the Constitutive Act of the AU provide for the settlement of dispute through peaceful means and this is equally consistent with the UN Charter. [27] Finally, there is no provision under the UN Charter and the AU on the one hand and under the ICJ and the ICC on the other hand that prohibits the existence of the ACC. Therefore, any question about the legality of the ACC is settled once and for all since it existence is recognized by international law and its statute is not inconsistent with any current international tribunal such as the ICC. In other words, the ACC Statute is consistent with international law principles. [28] The next issue that has to be examined is the legitimacy of the ACC since it legality is indisputable.

\subsection{The Legitimacy of the ACC}

In order to determine the legitimacy of the ACC, it is imperative to examine the ideas of legitimacy since it is an important tool for measuring the effectiveness of an institution and it credibility. The concept of legitimacy encompasses many principles. Firstly, legitimacy is the moral and psychological acceptance of a body which could either be a political system or an authority by its constituency. Therefore, a body politic whether domestic or international institution is considered legitimate when the majority of the population or institutional constituency expresses a high degree of consent and approval for it. The said institution or body politic will command respect and compliance for its act. We term this type of legitimacy "consent legitimacy". Secondly, purposive legitimacy is when majority of the constituency of a state, an authority or an institution believes that it is grounded on values principles and goals that reflect those of the whole community. [29] There is also "universal values legitimacy" and this legitimacy is based on the consistency of a body politic or institution with values common to the whole community within which the institution lives and operates. [30] For example, in the international community, it can be said that an institution to enjoys such legitimacy when it is grounded on or at least is not contrary to the peremptory norms of international law also known as jus cogens, or is based on the principles of justice as fairness. [31]

Based on the examination of the concepts of legitimacy above, there is no doubt that the ACC is a legitimate international court. Even though the court has not yet come into force given that the ratification process has been very slow, with only $15 \mathrm{AU}$ state members that have signed the Malabo Protocol, [32] the fact the ACC has proven beyond reasonable doubt to be a legal institution in international law created by a treaty mutata mutandis is also legitimate. [33] In other words, despite many critics, the Malabo Protocol creating the ACC has satisfied both the legality and legitimate test as an international criminal court. Additionally, like any other international court, the legitimacy of the court will be challenged when the court finally comes into operation. Some examples of such issues that will challenge the legitimacy of the ACC include the prosecutorial strategies, the judicial processes and political considerations. However, with proper legal design and support especially from the AU, all these hurdles will be overcome and the court will contribute significantly to the development of global rule of law and expand the family of international criminal law through the newly created crimes. In all, the difference between legality and legitimacy is summarized as follows:

The legality of an action or policy is assessed by reference to legal texts, case law, and precedents. Challenges and appeals may be raised as part of the adjudicative process, but there is a clear and final view either in favour or against. An action is always either legal or illegal; it cannot be partly legal. In contrast, legitimacy is fluid and changing - it depends on perceptions and outcomes. As a subjective interpretation of what is desirable and appropriate, legitimacy can be maintained by a constant effort to ensure conformity with the normative expectation of the affected constituents. Legitimate decisions are based in democratic participation whereby affected persons have 
opportunity to raise their voices. When legitimacy is separated from democratic participation, it risks being exposed to ideological and self-concerned manipulation. Legitimacy is a relative measure - it depends upon the perceived acceptability of the rules governing the act, and upon the actor itself. Nuremberg can illustrate this-the law was problematic both in substance and procedure and all prosecutors were from victor's state. Nevertheless, the two alternatives -amnesty or judicial execution - would have been even less legitimate. [34]

Finally, an international criminal court like the ACC must satisfy the legality and legitimacy test for it credibility. However, one of the key areas where the ACC has been heavily criticized is that it recognizes the immunities of serving senior African leaders. [35] As indicated earlier, the inclusion of this provision has raised many eyebrows about the credibility of the court. Therefore, in the last section under this head, I will examine the legality and legitimacy of Article 46A bis of the 2014 Malabo Protocol.

\subsection{The Legality and Legitimacy of the Immunities Provision}

The immunity provision under the 2014 Malabo Protocol appears to undermine both the legality and legitimacy of the ACC. This is so because contemporary international criminal court does not recognize any form of immunity of state officials if they are charged before its jurisdiction. [36] Accordingly, Article 46A bis of the 2014 Malabo Protocol read as follows:

No charges shall be commenced or continued before the Court [ACC] against any serving AU Head of State, or Government, or anybody acting or entitled to act in such capacity, or other senior state officials based on their functions, during their tenure of office. [37]

As indicated elsewhere, [38] however, the recognition of immunity under international criminal law is determined by the statute creating the court. [39] Moreover, despite the fact that the immunity provision in the 2014 Malabo Protocol seems to be inconsistent with the general fight against impunity in international criminal law in a narrow vision, [40] the aim and objectives of the ACC demonstrates otherwise in a wider vision. [41] In this regard, the recognition of the immunity ratione personae of AU senior serving state officials by the 2014 Malabo Protocol does not mean impunity. This is because the personal immunity of the state officials is granted based on their status and office and this immunity is consistent with the fight against impunity, and it ceases when the state official is longer in office. [42]

Additionally, just like the immunity provisions in the Rome Statute creating the ICC ignited a lot of debate as to whether the Rome Statute recognizes or waive the immunity of non-state parties, so too is the immunity provision in the 2014 Malabo Protocol creating the ACC which recognizes the immunity of senior serving AU state officials. In both cases, the immunities provisions are neither inconsistent with international law rule on the immunity of state officials nor the fight against impunity. [43] Accordingly, the legality and legitimacy of the immunity provision in the 2014 Malabo Protocol is unquestionable as well since these provisions are always determined by the statute creating the court on the one hand, and is also consistent with customary international law rule on the immunity of state officials on the other hand. Again, despite the fact that the immunity provision in the 2014 Malabo Protocol may be contrary to the principle of justice and fairness in the current trend of international criminal law, the ACC does fight against impunity of serious international crimes for the following reasons: (i) the fact only the immunity ratione personae of serving AU senior state officials is recognized before the Court; (ii) immunity ratione personae of senior serving AU state officials is also recognized by foreign criminal court and these courts are also against impunity; (iii) the recognition of the immunity of state officials under customary international law is determined by the statute creating the court and not international law; [44] and finally, (iv) the AU and African continent still have majority of the state parties that have ratified the Rome Statute, and more than half of the AU state members are still parties to the Rome Statute which does not recognized immunity before it jurisdiction. [45] This implies the Rome Statute is still applicable to more than 30 states out of the 55 states in Africa. Accordingly, if the AU intended to fight against impunity for serious international crimes using the immunity provision, then Rome Statute would not have been still applicable to AU state members and withdrawal from the Rome Statute would have been compulsory for AU state members. In other words, the immunity provision under the ACC does not hinders the fight against impunity for serious international crimes even though it may deters the senior serving $\mathrm{AU}$ of state officials from criminal responsibility while they are in office. [46]

In all, both the legality and legitimacy of the immunity provision under the ACC has been established. In other words, as indicated earlier, the immunity provision under the ACC seemed to have fulfilled with both the legality and legitimate test in international law. However, the credibility and legitimacy of the court will further be determined when it finally comes into operation taking into consideration the prosecutorial strategies and it judicial processes. In the next section, I will examine whether the ACC is the African panacea.

\section{Whether the Creation of the ACC Is the African Panacea}

In order to determine whether the ACC is the African panacea, two main issues have to be addressed: (i) the reason for the creation of the Court; (ii) the jurisdiction of the Court respectively.

\subsection{The Reason for the Creation of the ACC}

To begin with, the road that led to the creation of ACC began when some of the African state officials were indicted in Europe. [47] France for example, in 2009 indicted five African sitting heads of state namely: Denis Sassou Nguesso 
of Congo; Teodoro Obiang Nguema of Equatorial Guinea; Omar Bongo of Gabon; Blaise Compaore of Burkina Faso and Eduardo Dos Santos of Angola. [48] Their indictments and prosecutions by the European courts was a wakeup call for the AU to seek alternative means to handle criminal matters within the continent. Additionally, the Committee of eminent African jurist created by the $\mathrm{AU}$ in the Habre Hissene case also mapped the road for the creation of ACC. Accordingly; paragraph 36 on the Committee reports recommended the creation of an ACC which is a chamber in the ACJHPR in accordance with paragraph 26 of the Report.

Perhaps, as indicated earlier, the immediate cause for the creation of the ACC was the indictments of two African sitting heads of states by the ICC namely; President Al Bashir of Sudan who is now former President and President Uhuru Kenyatta of Kenya. [49] Although African states contributed enormously in the creation of the ICC, [50] the AU has accused the ICC of double standard, and also for prosecuting mostly African state officials. The immediate reaction was the creation of the ACC. [51] In June 2014; the AU adopted a Protocol on Amendment to the Protocol on the Statute of the African Court of Justice and Human Rights in Malabo, Equatorial Guinea. [61] The rationale for such amendment was to create a criminal chamber to the African Court of Justice and Human Rights which is now amended as ACJHPR. [52]

In sum, with regard to the reasons for the creation of the ACC, according to Professor Jalloh, they were four main reasons that led to the creation of the ACC. The first reason is about the legal duty of the African states to strengthen regional cooperation and enhance human security in Africa through the prosecution of international crimes. [53] This idea is also enshrined in the AU Constitutive Act of 2001. [54] The second reason for the creation of the ACC by the AU was the recommendation from the committee of eminent jurist in the Hissene Habre case. [55] The committee recommended an African criminal jurisdiction. The third reason for the creation of the ACC was the abuse of universal jurisdiction by European states as seen earlier from the example of France. [56] Finally the fourth reason and perhaps the most immediate and accurate was the AU-ICC relationship. [57] This relationship led to what I term "the AU debacle with the ICC" resulting from the prosecution of some serving African heads of state such as Al Bashir of Sudan and President Uhuru Kenyatta of Kenya. The above four factors summarized the reason for the creation of the ACC. The next issue to consider is the jurisdiction of the ACC.

\subsection{The Jurisdiction of the ACC}

Beside the criticisms labelled against Article 46A bis of the 2014 Malabo Protocol which recognizes the immunities of senior serving African state officials, the jurisdiction of the ACC is also a cause of concern to others. The ACC has wider jurisdiction as compared to the ICC with 14 international crimes. [58] Some of these crimes like the crime of unconstitutional change of government, mercenarism, illicit exploitation of natural resources money laundering and corruption are very common in Africa than any other continent. The ACC has consistent jurisdiction with the ICC to entertain widely accepted and recognisable serious international crimes such as genocide, crimes against humanity, war crimes and the crime of aggression. In other words, the ACC jurisdiction consists of both international and transnational crimes. [59]

Additionally, the court will exercise jurisdiction over any of the above crimes by virtue of Article 28A of the 2014 Malabo Protocol when the matter is referred to its jurisdiction by the Prosecutor through a state party, [60] Assembly of heads of state and government of AU or the Peace and Security Council of AU, [61] and proprio muto by the Prosecutor in exercising his or her power using his or her initiative on the basis of crimes within the jurisdiction. [62]

Even though the ACC jurisdiction entertains partly crimes which concerns the African continent and AU state members, [63] there is need for cooperation with other international criminal court like the ICC to enhance the fight against impunity for serious international crimes in the continent and globally. Therefore, the ACC simpliciter is the not the African panacea with regard to crimes committed in the continent for the following reasons: (i) the ratification process is very slow with only 15 states that have so far signed and no single ratification of the 2014 Malabo Protocol; (ii) the immunity provision in Article 46A bis of the 2014 Malabo Protocol hinders the effective prosecution of African state officials as some of these officials stays in power for more than three decades; (iii) the AU lacks the financial resources to set an effective ACC to prosecute crimes in the continent; (iv) the creation of the ACC is not fully supported by some proponents of the ICC and Western countries; (v) Article 12 (2) of the Rome Statute grant easy access to the jurisdiction of the ICC for African state officials whose states have ratified the Rome Statute.

It is certain that no international criminal court can properly function in isolation; there is always a vacuum that may only be fulfilled through cooperation with other international criminal court to ensure effective fight against impunity for core international crimes.

\section{Possible Harmonization of Certain Organs of the ACC with ICC for Impunity}

In the world of globalization where most countries and institutions are coming together for mutual benefits and explore the advantages offered by each other while minimizing the disadvantage, it is also imperative for international criminal tribunals to come together for a mutual cause. Therefore, harmonization of the ACC and the ICC to fight against impunity for the most serious international crimes is a condition sine qua non since the fight against impunity for these serious crimes is one of their main objectives. In this regard, under this penultimate section, I will examine vertical harmonization through complementarity at the international level and horizontal harmonization through cooperation at the 
national level. Finally, I will examine the motivations for harmonization in international criminal law with regard to the ACC and the ICC.

\subsection{Vertical Harmonization of the ACC with the ICC Through Complementarity}

Despite the differences created by their respective immunities provisions; with the ACC recognizing the immunity of senior serving AU state officials while in office before its jurisdiction, and the Rome Statute not recognizing or waiving all the immunities accorded to state officials before its jurisdiction, both the ACC and the ICC may harmonize vertically through complementarity.[64] According to the principle of complementarity, [65] the national jurisdiction of all the states parties are authorised to prosecute all the crimes under Article 5 of the Rome Statute. [66] The 2014 Malabo Protocol and the Rome Statute both have jurisdiction to entertain the crime of genocide, crimes against humanity, war crimes and the crime of aggression, consequently, the principle of complementarity will facilitate harmonization in this regard. Complementarity of the ACC and the ICC therefore will mean the following: (i) when a case is being investigated or prosecuted under the ACC jurisdiction, it will be inadmissible before the jurisdiction of the ICC unless the ACC is genuinely unwilling or unable to carry out the investigation or prosecution; [67] (ii) when the case has been investigated under the jurisdiction of the ACC and the court also decided genuinely not to prosecute the crime, the ICC should equally declared the crime inadmissible unless the decision taken by ACC not to prosecute the crime was based on unwillingness or inability not to prosecute; [68] (iii) when the crime has already been prosecuted or tried by the ACC for conduct that is subject to the complaint, the ICC should equally not have jurisdiction or considered the crime inadmissible; [69] (iv) finally when there is insufficient gravity to justify further action before the ACC jurisdiction, it should equally be inadmissible before the jurisdiction of the ICC. Beside complementary through the jurisdiction and judicial organs of the ACC and the ICC, the Offices of The Prosecutor of both the ACC and the ICC should complement each other especially during investigations and prosecutions of crimes. [70] Skilled and expert knowledge on investigation and prosecutions could be shared and in this regard harmonization through cooperation between the ACC and ICC for impunity cause. In all, the complementary jurisdiction of the ICC is a prototype and is replicated by the complementary jurisdiction of the ACC, hence harmonization is possible. Moreover, the harmonization of these jurisdictions will equally share the burden of investigations and prosecutions for the most serious crimes of international concern between the ACC and the ICC.

\subsection{Horizontal Harmonization of the ACC and the ICC Through Cooperation}

It is imperative to recall that 33 out of the $55 \mathrm{AU}$ state members are parties to the Rome Statute, and these state parties bound by the principle of complementarity to cooperate with the ICC. These 33 states will also cooperate with the ACC when it came into force through the national and regional courts of the AU. Here, the state parties for both the ACC and the ICC should cooperate and complement each other. [71] The cooperation by both states parties especially in matters of investigations, arrest and surrender of any accused person to either of the jurisdiction will be possible through horizontal harmonization of the various legal frameworks of both statutes on the one hand, and the avoidance of any conflicting of obligation on the other hand. Accordingly, the cooperation regime of the ACC is almost exactly as the ICC cooperation system. Article 86 of the Rome Statute obliges all state parties to cooperate fully during investigations and prosecutions of any of the crimes within its jurisdiction. [72] The requests to cooperate under the Rome Statute are made by the Court to state parties.[88] The ICC may also request any state on whose territory the accused is found to cooperate with the Court in relation to crimes within its jurisdiction. [73] The only limitation on cooperation under the Rome Statute is found in Article 98. This provision prohibits a state party to cooperate with the ICC where such obligation is inconsistent with respect to immunity under international law. [74] However, under the ACC there is no such limitation with regard to immunity since the statute of the Protocol recognises the immunity of state officials before its jurisdiction while the official is in office. [75] It is also possible that when the serving AU state official is no longer in office, cooperation between the $\mathrm{ACC}$ and the ICC will be further enhance given that they will be no hurdles. [76] Since both statutes are similar with regard to cooperation, harmonization therefore will eliminate any conflict of obligations between the various state parties and enhance the fight against impunity for serious international crimes. Finally, the cooperation of the ICC and the ACC will facilitate complementarity and burden sharing in the fight against impunity for serious international crimes before their respective jurisdictions. [77]

\subsection{The Motivation for Harmonization Subsides}

The harmonization of the ACC and the ICC will cement their relationship. Accordingly, instead of a tense relationship, harmonization will breakdown the barrier through complementarity between the ACC and the ICC since both institutions shares the same jurisdiction regarding the most serious crimes of international concern. [78] Another rationale for the harmonization of the ACC and the ICC is that it will lead to a better fight against impunity through cooperation. Instead of competing against each; harmonization will lead to the efficient use of resources to fight against impunity. This will eventually maximise the criminal budget of both the ACC and the ICC often spent during investigations and prosecutions one the hand, and also prevent double jeopardy on the other hand. Moreover, harmonization of the ACC and the ICC would strength both their legality and legitimacy as outstanding international criminal institutions and the eventually universality of the ICC for crimes within its jurisdiction. [79]

Harmonization will certainly create a symbiotic 
relationship between the ACC and the ICC and further enhance the fight against impunity for serious international crimes affecting our society. [80] Moreover, harmonization through complementarity will empower the ACC judges as they would have access to the ICC jurisprudence on complementarity and other matters handled by the ICC judges. [81]This is also possible because both jurisdictions have similar provisions relating to complementarity. [82] Finally, harmonization will facilitate positive complementarity and promote burden sharing between the ACC and the ICC. [83] Indeed, harmonization between the ACC and the ICC will avoid jurisdictional overlaps. [84]

\section{Concluding Remarks}

The harmonization of the ACC and the ICC will create an undefeatable tag team that will fight against impunity for international crimes in the Africa continent and the rest of the world. In other words, the tag team created by the ACC and the ICC through harmonization to fight against impunity for the most serious crimes of concern to the international community as a whole will be the most dangerous and most powerful panacea against impunity for serious international crimes. Therefore, instead of competing and challenging each other, resulting in a debacle, the ACC and the ICC should complement each other and cooperate for the ultimate fight against impunity for serious international crimes. Moreover, since the legality and legitimacy of both criminal institutions has been justified and indisputable, it is time to reduce and possible eradicate impunity for international crimes in the African continent in particular, and globally as a whole, using the tag team vaccine created when the ACC and ICC come together for a single cause through harmonization. The ACC is therefore not an African alternative but complementary to the ICC. Cooperation between the two courts is imperative since both the ACC and the ICC are different players in the same team with the objective to win the fight against impunity for the most serious crimes of international concern.

\section{References}

[1] See generally Jalloh, C. C. The Place of African Court of Justice and Human and Peoples Rights in the Prosecution of Serious Crimes in Africa in Jalloh, C. C. Clarke, K. M. \& Nmehielle V. O., Eds., The African Court of Justice and Human Rights in Context: Development and Challenges, Cambridge, Cambridge University Press, 2019, pp. 57-108.

[2] See Rome Statute of the International Criminal Court circulated as document A/CONF. 183/9 of 17 July 1998 and came into force on 1 July 2002 (Rome Statute), Retrieved 13 February 2021 from https://www.icc-int/resource-library.

[3] See Situation under Investigation Retrieved 19 February 2021 from https://www.icc-cpi.int/pages/situation.aspx.

[4] See Magliveras, K. D. \& Naldi, G. J. (2013), The International Criminal Court's Involvement with Africa: Evaluation of a Fractious Relationship Nordic Journal of International Law, 82,417 .
[5] See Decision on Africa's Relationship with the International Criminal Court AJICJ, 2015, 90-92.

[6] See Ssenjonjo, M. (2013), The Rise of the African Union Opposition to the International Criminal Court's Investigations and Prosecutions of African Leaders International Criminal Law Review, Vol. 13, 2013, pp. 385386, noting that according to former ICC President SangHyun Song the AU state members played a very important role prior to and during the creation of the ICC and perhaps without the Africa's support the Rome Statute would never have been adopted.

[7] See Van de Vyver, J. D. (2015), The Al Bashir Debacle, African Human Rights Law Journal, 15 (2), 559-579.

[8] See L. Mushoriwa, L. (2018), Immunity before the International Criminal Court: Still hazy after all these years South African Journal of Criminal Justice, 31 (3), 339-360.

[9] See Art. 46A bis of the 2014 Malabo Protocol and Art. 27 of the Rome Statute.

[10] The three notable situations here include the indictments of President Kenyatta of Kenya, Retrieved 13 February 2021 from https://www.icc-cpi.int/kenya/kenyatta; President Al Bashir of Sudan, Retrieved 13 February 2021 from https://www.icc-cpi.int/darfur/albashir and President Gadhafi of Libya Retrieved 13 February 2021 from https://www.icccpi.int/libya/gaddafi.

[11] For example Senegal was the first state in the world to ratify the Rome Statute, Retrieved 13 February 2021 from https://www.icc-cpi.int/Pages/item.aspx?name=pr1462.

[12] For example some of the cases referred to the ICC's jurisdiction by African state officials are situation in the Democratic Republic of Congo (DRC) referred by the DRC government, Retrieved 13 February 2021 from https://www.icc-cpi.int/drc; Situation in Uganda referred by the Ugandan government, Retrieved 13 February 2021 from https://www.icc-cpi.int/uganda; and the situation in Central African Republic (CAR) referred by the CAR government, Retrieved 13 February 2021 from https://www.icc-cpi.int/car.

[13] See Art. 46A bis of the 2014 Malabo Protocol recognizing the personal immunities of senior African state officials while in office.

[14] See Cassese, A. (2012), The Legitimacy of International Criminal Tribunals and the Current Prospects of International Criminal Justice, Leiden Journal of International Law, 25, 492.

[15] See Black Law free online dictionary, Retrieved 16 February 2021 from https://www.freelawdictionary.org/legality.

[16] See the Charter of the United Nations that was signed on 26 June 1945 in San Francisco and came into force on 24 October 1945, Retrieved February 2021 from https://www.un.org/en/charter-united-nations/index.html (the 1948 UN Charter).

[17] See Tladi, D. Article 46A Bis: Beyond the Rhetoric in Jalloh, C. C. Clarke, K. M. \& Nmehielle, V. O., Eds., The African Court of Justice and Human and Peoples' Rights in Context: Development and Challenges, Cambridge, Cambridge University Press, 2019, pp. 850-865.

[18] For example the hybrid or mixed chambers created by the UN in Cambodia, Lebanon, East Timor and Kosovo. 
[19] With regard to the ad hoc tribunal references to be considered here are the Nuremberg and the Tokyo Tribunals, the International Criminal Tribunal for the former Yugoslavia (ICTY), the International Criminal Tribunal for Rwanda (ICTR) and the Special Tribunal for Sierra Leone (SCSC) created either directly or as subsidiary body of the United Nations Security Council (UNSC). With respect the permanent court such as the ICC and the ACC, they were created by multilateral treaty and are regarded as treaty-based international criminal court.

[20] Examples here are Belgium, Australia, Canada, France and Senegal. All these countries have domestic jurisdiction to entertain international crimes.

[21] See Art. 95 of the 1948 UN Charter.

[22] See Protocol on Amendment to the Protocol on the Statute of the African Court of Justice and Human Rights of the African Union, Retrieved 21 February from https://au.int/en/treaties/protocol-amendments-protocolstatute-african-court-justice-and-human-rights (the 2014 Malabo Protocol).

[23] See Onoma, A. K. (2016), An Epochal Bifurcation: The International Criminal Court, the African Court and the Struggle against Gross Human Rights Abuses, African Journal of International Criminal Justice (AJICJ), 29, 32; Tilden, S. T. (2018), Africa's Conflict with the International Criminal Court: The African Court of Justice and Human and People's Rights' as an Alternative to ICC', Tulane Journal of International and Comparative Law, 27 (1). 202-203.

[24] See also Abebe, Z. B. (2017), The African Court with a Criminal Jurisdiction and the ICC: A Case for Overlapping Jurisdiction, African Journal of International and Comparative Law, 25, 418-420.

[25] See generally the objectives of the AU enshrined in Art. 3 of the Constitutive Act of the A U adopted on 7 November 2000 and came into force on 26 May 2001, Retrieved 21 February 2021 from https://au.int/en/treaties/constitutive-act-africanunion (the 2001 Constitutive Act of the AU).

[26] See Art. 52 of the 1948 UN Charter.

[27] Cassese, A. (2012) The Legitimacy of International Criminal Tribunals and the Current Prospects of International Criminal Justice, Leiden Journal of International Law, 25, 492.

[28] See Peake, J. The Institutional Framework of the Office of the Prosecutor, Legitimacy, and Overcoming Bias Allegations in R. H. Steinberg Ed., Contemporary Issues Facing the International Criminal Court, Leiden Brill Njihoff 2016, pp. 353-354.

[29] Cassese, A. (2012), The Legitimacy of the International Criminal Tribunal and the Current Prospect of International Criminal Justice, Leiden Journal of International Law, 25, 492-493.

[30] With the exception of the immunity provision in the Malabo Protocol as examined below, the ACC has passed the legitimacy test.

[31] As of 23 February 2021 only 15 states have signed the 2014 Malabo Protocol, and no single state has ratified the Protocol available on Protocol on Amendments to the Protocol on the Statute of African Court of Justice and Human Rights, $\begin{array}{lllll}\text { Retrieved } & 23 & \text { February } & 2021 & \text { from }\end{array}$ https://au.int/en/treaties/protocol-amendments-protocolstatute-african-court-justice-and-human-rights.

[32] However, the legitimacy of the court will be put to test when it finally comes into force.

[33] See Cassese, 2012, The Legitimacy of International Criminal Tribunals and the Current Prospects of International Criminal Justice, Leiden Journal of International Law, 25 p. 493.

[34] For example, see Art. 27 of the Rome Statute.

[35] Art. 46A bis of the 2014 Malabo Protocol.

[36] Aghem, H. E (2020) The ICC or the ACC: Defining the Future of the Immunities of African State Officials, AJICJ, 6, $50-72$.

[37] Tladi, D. (2015), The Immunity Provision in the AU Amendment Protocol', Journal of International Criminal Justice (JICJ), 13, 14.

[38] The fact that it recognizes the immunity ratione personae of serving senior AU state officials which is procedural in nature and will cease when the state official is no longer in office.

[39] The fact that the ACC does not recognize the immunity ratione materiae of former AU state officials in respect of international crimes is consistent with the fight against impunity.

[40] See Gaeta, P. (2003), Ratione Materiae Immunities of Former Head of State and International Crimes: The Hissene Habre Case' JICJ, 1, 186-1867.

[41] See Pedretti, R. (2016), Immunity of Heads of State and State Officials for International Crimes, Swiss Review of International and European Law, 26 (4), 758-762.

[42] Tilden, S. T. (2018) Africa's Conflict with the International Criminal Court: The African Court of Justice and Human and People's Rights' as an Alternative to ICC', Tulane Journal of International and Comparative Law, 27 (1). 202-203.

[43] Abebe, Z. B. (2017), The African Court with a Criminal Jurisdiction and the ICC: A Case for Overlapping Jurisdiction, African Journal of International and Comparative Law, 25, 418-420.

[44] Abebe, Z. B. (2017), The African Court with a Criminal Jurisdiction and the ICC: A Case of Overlapping Jurisdiction, African Journal of International and Comparative Law. 25, 59-62.

[45] See generally Arts. 27 and 98 of the Rome Statute.

[46] Gaeta, P. (2003), Ratione Materiae Immunities of Former Head of State and International Crimes: The Hissene Habre Case' JICJ, 1, p. 187.

[47] See Five African Leaders sued for Corruption in Radio France International, Retrieved 14 February 2021 from http://www.rfi.fr/actuen/articles/103/article.960.asp; Murungu, 2011, p. 1070.

[48] See Decision on Africa's Relationship with the International Criminal Court (ICC), AJICJ, 2015. p. 91, paragraphs 10 (iv) indicates the intention to expand the mandate of the African Court on Human and Peoples Rights (AfCHPR) with a criminal chamber to try crimes such as genocide, crimes against humanity and war crimes. 
[49] See paragraphs 26, 36 and 36 of the Report on the Committee of Eminent African Jurist on the case of Hissene Habre, presented to the Summit of the African Union in July 2006 ,

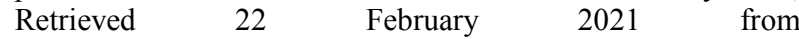
http://www.hrw.org/justice/habre/CEJA_Repor0506.pdf.

[50] Brown, B. S. (2017), The International Court in Africa: Impartiality, Politics, Complementarity and Brexit Temple International \& Comparative Law Journal, 31, p. 165; Tilden, S. J, (2018), Africa's Conflict with the International Criminal Court: The African Court of Justice and Human and Peoples' Right as an Alternative to the ICC, Tulane Journal of International \& Comparative Law, 27, p. 202.

[51] See Bachmann S. D. D \& Nwibo, E. L. (2018), Pull and PushImplementing the Complementary Principles of the Rome Statute of the ICC with the African Union: Opportunities and Challenges Brook. Journal of International Law, 43, 523.

[52] See Ssekandi, F. \& Tesfay, N. (2017), Engendered Discontent: The International Criminal Court in Africa' Georgetown Journal of International Affairs, 18, 77.

[53] Abebe, Z. B. (2018), The African Court with a Criminal Jurisdiction and the ICC: A Case for Overlapping Jurisdiction' African Journal of International and Comparative Law, 25, 418.

[54] See Art. 8 of the 2014 Malabo Protocol.

[55] See Murithi, T The Advent of a Differentiated Accountability System' in Jalloh, C. C. Clarke, K. M. \& Nmehielle, V. O., Eds., The African Court of Justice and Human and Peoples' Rights in Context: Development and Challenges, Cambridge, Cambridge University Press, 2019, p. 171.

[56] Cannon, B. J. Pkalya, D. R. \& Maragia, B.(2016), The International Criminal Court and Africa', African Journal of International Criminal Justice, 6, 20.

[57] By virtue of Art. 28A (1) of the 2014 Malabo Protocol, the Court has power to prosecute 14 international crimes as follows: Genocide, Crimes against humanity, War crimes, the Crime of Unconstitutional change of Government, Piracy, Terrorism, Mercenarism, Corruption, Money laundering, Trafficking in persons, Trafficking in drugs, Trafficking in hazardous waste, Illicit expropriation of natural resources and the Crime of Aggression.

[58] See Jalloh, C. C. A Classification of the Crimes in the Malabo Protocol' in Jalloh, C. C. Clarke, K. M. \& Nmehielle, V. O., Eds., The African Court of Justice and Human and Peoples' Rights in Context: Development and Challenges, Cambridge, Cambridge University Press, 2019, p. 231.

[59] See Art. 46F (1) of the 2014 Malabo Protocol.

[60] See Art. 46F (2) of the 2014 Malabo Protocol.

[61] For example the crimes of unconstitutional change of government, corruption, and illicit expropriation of natural resources are very common in Africa.

[62] See Art. 1 of the Rome Statute. Art. 4 (2) of the Rome Statute also states that the Court may exercise its jurisdiction on the territory of any state party; The Minister of Justice and Constitutional Development $\mathrm{v}$ The Southern African Litigation Centre (867/15) [2016] ZASCA 17 (15 March 2016).

[63] J. N. Foster, J. N. (2016), A Situational Approach to Prosecutorial Strategy at the International Criminal Court Georgetown Journal of International Law, 47 (2), p. 460.
[64] See Report of the Bureau on Complementarity Retrieved 29 January 2021 from https://www.icc-cpi.int/Pages/searchresults.aspx?k=Definition $\% 20$ of $\% 20$ the $\% 20$ complementarity $\% 20 p$ rinciple (the ICC-ASP 2020 Report on Complementarity).

[65] See Amoroso, A. M. (2018), Should the ICC Assess Complementarity With Respect to Non-state Armed Groups? Journal of International Criminal Justice, 16, 1068.

[66] See Art. 17 (1) (a) of the Rome Statute; Art. 46H (2) (a) of the 2014 Malabo Protocol.

[67] See Art. 17 (1) (b) of the Rome Statute; Art. 46H (2) (b) of the 2014 Malabo Protocol.

[68] See Art. 17 (1) (c) of the Rome Statute; Art. 46H (2) (c) of the 2014 Malabo Protocol.

[69] See Art. 17 (1) (d) of the Rome Statute; Art. 46H (2) (d) of the 2014 Malabo Protocol.

[70] See generally Art. 15 of the Rome Statute; Art. 46G of the 2014 Malabo Protocol.

[71] Ani, N. C. (2018), Implications of the African Union's Stance on Immunity for Leaders on Conflict Resolution in Africa: The Case of South Sudan and Lessons from the Habre Case', African Human Rights Law Journal, 18 (2), 454.

[72] See Art. 46H (1) of the 2014 Malabo Protocol.

[73] See Art. 46Lof the 2014 Malabo Protocol.

[74] See Tladi, D. (2019), Promoting an Effective Cooperative Regime in Jalloh, C. C. Clarke, K. M. \& Nmehielle, V. O., Eds., The African Court of Justice and Human and Peoples' Rights in Context: Development and Challenges, Cambridge, Cambridge University Press, 2019, p. 738.

[75] See generally Part IX from Arts. 86 to 102 of the Rome Statute dealing with cooperation and judicial assistance and Art. 46L of the 2014 Malabo Protocol.

[76] See Art. 86 of the Rome Statute.

[77] See generally Art. 87 of the Rome Statute.

[78] See generally Art. 89 of the Rome Statute.

[79] See generally Art. 98 of the Rome Statute. This provision is applicable only with respective to the immunity accorded by international law to non-state parties since all state parties have agreed to waive the immunities of their state officials with respect to crime under the jurisdiction of the Court as Art. 27 of the Rome Statute.

[80] The 2014 Malabo Protocol creating the ACC only recognizes the personal immunity of senior serving AU state officials while in office. This immunity subsides immediately when the mandate of the state official comes to an end.

[81] See Aghem, 2020, p. 65, noting that the future of the immunities of African state officials will be determined by a blend of the ACC and the ICC through some comprises from both criminal courts.

[82] De Wet, E. Concurrent Jurisdiction of the International Criminal Court and the African Criminal Chamber in Case of Concurrent Referrals' in Jalloh, C. C. Clarke, K. M. \& Nmehielle, V. O., Eds., The African Court of Justice and Human and Peoples' Rights in Context: Development and Challenges, Cambridge, Cambridge University Press, 2019, pp. 190-196. 
[83] DeGuzman, M. M. Complementarity at the African Court', in Jalloh, C. C. Clarke, K. M. \& Nmehielle, V. O., Eds., The African Court of Justice and Human and Peoples' Rights in Context: Development and Challenges, Cambridge, p. 663.
[84] See for example both Art. 17 of the Rome Statute and Art. $46 \mathrm{H}$ of the 2014 Malabo Protocol respectively. 